\title{
Geochemistry of Trace Elements as One of the Important Coal Quality Parameter: An Example from Balingian Coal, Malaysia
}

(Geokimia Unsur Surih Sebagai Salah Satu Parameter Penting dalam Kualiti Arang Batu: Contoh dari Arang Batu Balingian, Malaysia)

\author{
SAY-GEE SiA* \& WAN HASIAH ABDULlaH
}

\begin{abstract}
Ash and sulphur are the two main variables that influence coal quality and are therefore very important contractual parameters in a coal supply agreement. Coal which is low in ash yield and sulphur content is considered as 'cleaned coal'. Nonetheless, combustion of coal is also known to release toxic trace elements, which are known or suspected to be carcinogenic and may also cause respiratory problems, pregnancy complications, premature mortality and possibly a wide range of health problems. The two traditionally used coal quality parameters have proven to be insufficient for defining 'cleaned coal'. This is evidenced by the low ash and low sulphur Balingian coals that is seen as relatively safe in environmental terms, but still contains high concentrations of potentially hazardous trace elements which may pose health and environmental threats during coal combustion. Therefore, a comprehensive assessment of coal quality should also include information on concentration, spatial distribution and modes of occurrence of trace elements, particularly the 15 potentially hazardous trace elements identified by the United States Clean Air Act Amendments (1990).
\end{abstract}

Keywords: Ash; coal; potentially hazardous trace elements; sulphur

\section{ABSTRAK}

Abu dan sulfur adalah dua pemboleh ubah utama yang mempengaruhi kualiti arang batu. Ia merupakan parameter kontrak yang amat penting dalam perjanjian bekalan arang batu. Arang batu yang rendah dalam kandungan abu dan kandungan sulfur dianggap sebagai 'arang batu bersih'. Walau bagaimanapun, pembakaran arang batu juga diketahui melepaskan unsur-unsur surih toksik, yang diketahui atau disyaki karsinogen dan juga boleh menyebabkan masalah pernafasan, komplikasi kehamilan, kematian pra-matang dan juga pelbagai masalah kesihatan. Kedua-dua parameter kualiti arang batu yang digunakan secara tradisi telah terbukti tidak mencukupi untuk menentukan 'arang batu bersih'. Ini telah terbukti dengan arang batu Balingian yang mengandungi abu dan sulfur yang rendah dan dilihat sebagai selamat daripada segi alam sekitar, tetapi ia mengandungi kandungan tinggi unsur surih yang berpotensi merbahaya yang boleh menimbulkan masalah kesihatan dan ancaman alam sekitar semasa pembakaran arang batu. Oleh itu, penilaian menyeluruh kualiti arang batu juga perlu memasukkan maklumat mengenai kepekatan, taburan dan mod kehadiran unsur-unsur surih, terutamanya 15 unsur surih yang berpotensi merbahaya yang telah dikenal pasti oleh Akta Udara Bersih Pindaan Amerika Syarikat (1990).

Kata kunci: Abu; arang; sulfur; unsur surih berpotensi bahaya

\section{INTRODUCTION}

Coal combustion is known to produce large quantities of hazardous air pollutants that have the potential to cause a wide range of health and environmental problems. The four principal hazardous air pollutants associated with coal combustion which was included in the list of the hazardous air pollutants of the Clean Air Act Amendments 1990 are sulphur dioxide $\left(\mathrm{SO}_{2}\right)$, nitrogen oxides (NOx), particulate matter (PM) and carbon dioxide $\left(\mathrm{CO}_{2}\right)$. Besides the four major pollutants, combustion of coal is also known to release toxic trace elements, particularly the 15 potentially hazardous trace elements identified by the United States Clean Air Act Amendments (US Public Law 1990). The 15 potentially hazardous trace elements are arsenic, beryllium, cadmium, chlorine, chromium, cobalt, fluorine, mercury, manganese, nickel, lead, antimony, selenium, thorium and uranium. Environmental and health impacts of coal burning are generally related to the concentration, toxicity and modes of occurrence of various trace elements in the coal (Finkelman 1995). A highly toxic element is dangerous even at very low concentrations, whereas a benign element remains harmless at relatively high concentrations. Some elements, such as selenium, nickel, manganese and zinc are essential to humans at low concentrations but are toxic to humans and ecosystems at higher concentrations (Frankenberger \& Engberg 1998; Fuge 2005; Miller 2011; Wang et al. 2010).

Although potentially hazardous trace elements only present in parts per million levels in coal, as a result of 
coal combustion several tons of these pollutants might be released to the environment (Vejahati et al. 2010). Many coal combustion-related health problems, such as arsenism, fluorosis, selenosis, mercurialism and berylliosis (beryllium poisoning), have been reported in many developing countries (Table 1), especially where mineralized coals are used in open, unvented ovens in homes for cooking, home heating and food drying (Dai et al. 2012; Ding et al. 2001; Finkelman et al. 1999; Tang et al. 2009; Zhao et al. 2008) or where residential areas are within the range of emissions from coal-fired power plants (Fuge 2005; Keegan et al. 2006; Thornton et al. 2003). Despite of this, trace elements analysis has only been carried out in three of the fifteen coalfields in Malaysia viz. Mukah, Balingian and Merit coalfields.

\section{THEORETICAL FRAMEWORK}

The concentration of trace elements differs greatly between and within coal seams and coalfields. Though coals with unusually high concentrations of trace elements are quite rare, they have been reported in many coal basins worldwide (Dai et al. 2012). Anomalous concentrations of trace elements in coals are usually related to source rock, volcanic ash, groundwater and magmatic/hydrothermal fluids (Baruah et al. 2005; Dai et al. 2012a, 2005; Finkelman 1993; Ren et al. 1999; Sun et al. 2010; Zhang et al. 2002), which accumulated in coals from the earliest peat-accumulation stage to the latest anthracite stage (Seredin \& Finkelman 2008).

The adverse health and environmental effects caused by the use of coal, especially as fuel for the coal-fired power plant, has become a focus of debate over the need of energy against the desire to maintain a healthy physical and social environment. The health and environmental threats posed by inorganic toxic elements in coal are the potential release of these elements from coal to the environment during coal combustion and their potential hazard in groundwater if they are leached from coalmining waste, or from fly ash at disposal sites. Such hazards are of great public concern (Diehl et al. 2012; Miller 2011; Schweinfurth 2003; Swaine \& Goodarzi 1995; US EPA 2000; US Public Law 1990; Vejahati et al. 2010; Zheng et al. 1999). Nonetheless, the potential hazard of the inorganic toxic elements to the groundwater is beyond the scope of this study. Therefore only the potential release of these elements to the environment as HAPs during coal combustion will be discussed in detail.

\section{BALINGIAN COALFIELD}

Balingian coalfield is located in the low-lying coastal plain between the Mukah and the Balingian Rivers of Sarawak, Malaysia covering an area of approximately $410 \mathrm{~km}^{2}$ (Figure 1). Accumulation of Balingian coal took place in the Liang Formation during Upper Pliocene in fresh-water ombrotrophic raised bogs (Sia \& Abdullah 2012b), though fauna identified suggests a brackishwater depositional environment in the coal zone, while the sediments outside the coal zone were deposited in a very shallow, near-shore type of marine depositional environment (Lietchi et al. 1960; Wolfenden 1960).

The Liang Formation is unconformably underlain by the Upper Eocene Metah Member of the Belaga Formation in the south and by the Lower Pliocene Begrih Formation in the north (Figures 2 and 3) (Wolfenden 1960). The Belaga Formation is a highly deformed deep-water turbidity deposit of the Upper Cretaceous to the Upper Eocene age (Lietchi et al. 1960; Wolfenden 1960). The sediments consist of intensely folded thinly interbedded sandstones with shales, mudstones, argillites and slates. The Begrih Formation consists of conglomerates, conglomeratic sandstones, mudstones, shales, tuffs and also coal beds. The formation contains mixed marine and brackish-water fauna, suggesting depositional conditions that were probably predominantly littoral (Wolfenden 1960).

The unconsolidated Liang Formation is approximately $950 \mathrm{~m}$ thick (Figure 3) and is made up of thick and structureless clays, sands, tuffs, coal seams and gravel lenses. Accumulation of Balingian coal took place in the Liang Formation, which hosted five potentially economic coal seams, ranging in thickness from 1.40$7.38 \mathrm{~m}$, with a cumulative thickness of $22.42 \mathrm{~m}$. The coal is subbituminous $\mathrm{C}$ in rank and is characterized by high moisture, low ash yield and low sulphur content. Mining activities were initiated in the Balingian coalfield in 2007. A total of 1.2 Mt of Balingian coal were extracted annually to fuel the $270 \mathrm{Mw}$ capacity mine-mouth Mukah Coal-Fired Power Station.

TABLE 1. Known health effects of coal combustion (Finkelman \& Bunnell 2003)

\begin{tabular}{ll}
\hline Trace Elements & Known health effects \\
\hline Arsenic & China - Skin Cancer $\sim 10,000$ people \\
& Czechoslovakia - Impaired hearing in children \\
Fluorine & Fluorosis affects 15 Million+ in China \\
Selenium & Selenosis in China $\sim 500$ people \\
& Fish kills - Texas, North Carolina \\
Mercury & Various health problems in pregnant women and populations eating Hg contaminated fish \\
Beryllium & Increased autoantibodies - Czechoslovakia \\
\hline
\end{tabular}



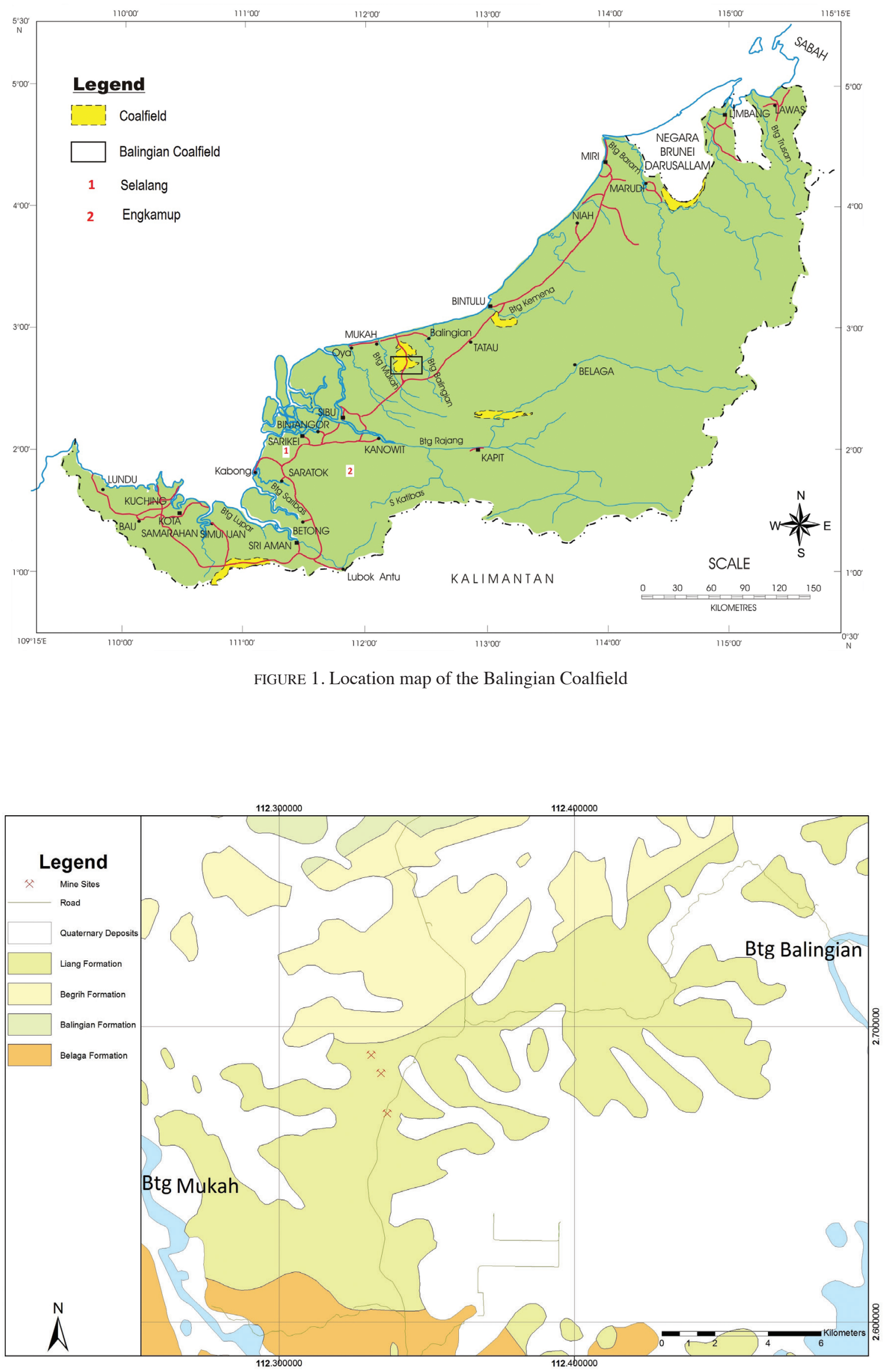

FIGURE 2. The geology of the study area 


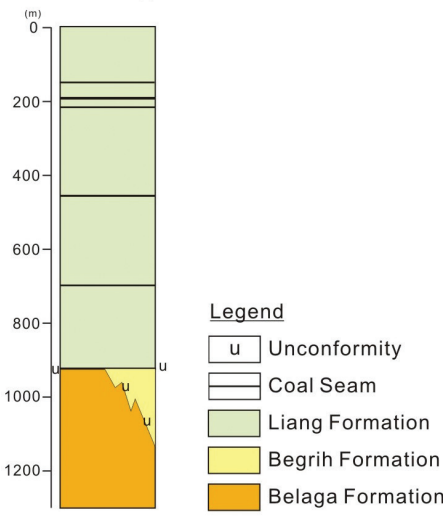

FIGURE 3. Generalised stratigraphic column of the study area

\section{CONCENTRATION OF TRACE ELEMENTS}

Balingian coal is highly enriched in arsenic (as high as $181 \mathrm{ppm})$, lead (325 ppm) and antimony (96 ppm) compared with their respective Clarke values (Sia \& Abdullah 2012a). The arithmetic means of arsenic, lead and antimony in Balingian coal are 102, 187 and 76 ppm respectively, which are much higher than their respective coal Clarke values of 7.6, 6.6 and $0.84 \mathrm{ppm}$ (Ketris \& Yudovich 2009). These three elements have been listed as potentially hazardous trace elements by the United States Clean Air Act Amendments (1990). They are therefore of considerable health and environmental concern. As such, it is important that coal beds with high concentrations of arsenic, lead and antimony in the Balingian coalfield be avoided through selective mining.

Anomalous concentrations of arsenic, lead and antimony in Balingian coal, may be related to the stibnite-realgar and probably spalerite mineralization in the Selalang and Engkamup areas in the vicinity of the Balingian coalfield (Figure 1). Arsenic, lead and antimony might have been eroded or leached from the mineralized source rocks, which were subsequently transported and precipitated syngenetically in the coal-forming peat swamps. Leaching of these elements from the surrounding rocks, and subsequent re-deposition epigenetically in the upper part of the coal seams by the descending groundwater carrying them in solution could also have occurred (Sia \& Abdullah 2012a).

\section{MODES OF OCCURRENCE}

The mode of occurrence of an element is a description of the manner in which an element is chemically bound in the host material. Trace elements can either be organically or inorganically associated, or occur simultaneously in both forms (Alto 1998; Gürdal 2011, 2008; Raask 1985; Radenovic 2006; Swaine 1990). An element is considered organically associated if it is bound with coal macerals or associated in the pore water of the coal; the element is inorganically associated if it is in the discrete mineral grains in coal (Clarke \& Sloss 1992; Stach 1982; Vassilev \& Vassileva 1996; Ward 2002).
The modes of occurrence of a trace element in coal may determine the cleanability potential of a trace element. Inorganically associated trace elements can be effectively removed, to a large extent, by applying physical cleaning technologies; this is not, however, applicable for organically associated trace elements (Alto 1998). Arsenic, lead and antimony are mostly organically and to a lesser extent, they are bound to discrete minerals in the form of aluminosilicates in the Balingian coal. Therefore, a major portion of the arsenic, lead and antimony cannot be easily removed by physical cleaning technologies.

The modes of occurrence of a trace element in coal can affect the way the trace element behaves during coal combustion (Tewalt et al. 2001; Vejahati et al. 2010) and thus will have different health and environmental impacts (Finkelman \& Gross 1999; Finkelman et al. 1999; Huggins 2002; Tewalt et al. 2001). The organically and associated trace elements tend to be vaporized, either escaping to the atmosphere or are adsorbed on the fine fly ash particles upon combustion in the furnace. The inorganically associated elements are generally non-volatile or have very low volatility and tend to be retained in the bottom ash and in the fly ash particles upon combustion (Dai et al. 2010; Finkelman 1994; Huang et al. 2004; Liu et al. 2005, 2004; Querol et al. 1995; Spears \& Zheng 1999; Vassilev \& Braekman-Danheux 1999; Vejahati et al. 2010), though partitioning of trace elements also depends on the natural volatility of these elements (Clarke \& Sloss 1992; Miller 2011; Querol et al. 1995; Suárez-Ruiz \& Ward 2008; Vejahati et al. 2010).

\section{CONCLUSION}

Though low ash yield and low total sulphur content in the Balingian coal are seen as relatively safe in environmental terms, nonetheless, Balingian coal is highly enriched in arsenic, lead and antimony compared with their respective Clarke values which may pose health and environmental threats during coal combustion. These elements are mostly organically bound and hence cannot be effectively removed by physically cleaning technologies. Analytical results indicated that a substantial portion of the organically associated arsenic, lead and antimony in the Balingian coal vaporize and are released into the atmosphere during coal combustion in the power plant; as such, coal-fired power plants burning similar coal may pose health and environmental risks if they are not fitted with appropriate emission control devices. Therefore, to ensure an environmental friendly use of coal, it is important to understand the quality of the coal without limiting to the two traditional coal quality parameters (ash and sulphur) but also the potentially hazardous trace elements. It is crucial that potentially hazardous trace elements are reduced to safe levels through selective mining, coal cleaning or emission control measures. 


\section{ACKNOWLEDGEMENTS}

The study received financial support from the University of Malaya IPPP research Grant No. FP042-2013A. The authors wish to thank Mr. Jaithish John, Principal Geoscience Officer of the Minerals and Geoscience Department Malaysia, for various forms of assistance provided.

\section{REFERENCES}

Alto, P. 1998. Assessment of Coal Cleaning for Trace Element Control.EPRI, TR-111852.p. 110.

Baruah, M.K., Kotoky, P., Baruah, J. \& Bora, G.C. 2005. Extent of lead in high sulphur Assam coals. Fuel Process. Technol. 86: 731-734.

Clarke, L.B. \& Sloss, L.L. 1992. Trace Elements - Emissions from the Coal Combustion and Gasification. London: IEA publication. p. 111.

Dai, S., Ren, D., Chou, C., Finkelman, R.B., Seredin, V.V. \& Zhou, Y. 2012. Geochemistry of trace elements in Chinese coals: A review of abundances, genetic types, impacts on human health, and industrial utilization. Int. J. Coal Geol. 94: 3-21.

Dai, S., Zhou, Y., Zhang, M., Wang, X., Wang, J., Song, X., Jiang, Y., Luo, Y., Song, Z., Yang, Z. \& Ren, D. 2010. A new type of $\mathrm{Nb}$ (Ta)-Zr(Hf)-REE-Ga polymetallic deposit in the late Permian coal-bearing strata, eastern Yunnan, southwestern China: Possible economic significance and genetic implications. Int. J. Coal Geol. 83: 55-63.

Dai, S., Ren, D., Tang, Y.G., Yue, M. \& Hao, L.M. 2005. Concentration and distribution of elements in Late Permian coals from western Guizhou Province, China. Int. J. Coal Geol. 61: 119-137.

Diehl, S.F., Goldhaber, M.B., Koenig, A.E., Lowers, H.A. \& Ruppert, L.F. 2012. Distribution of arsenic, selenium, and other trace elements in high pyrite Appalachian coals: Evidence for multiple episodes of pyrite formation. Int. J. Coal Geol. 94: 238-249.

Ding, Z., Zheng, B., Long, J., Belkin, H.E., Finkelman, R.B., Chen, C., Zhou, D. \& Zhou, Y. 2001. Geological and geochemical characteristics of high arsenic coals from endemic arsenosis areas in southwestern Guizhou Province, China. Appl. Geochem. 16: 1353-1360.

Finkelman, R.B. 1993. Trace and minor elements in coal. In Organic Geochemistry, edited by Engel, M.H. \& Macko, S.A. New York: Plenum Press. pp. 593-607.

Finkelman, R.B. 1994. Modes of occurrence of potentially hazardous elements in coal: Levels of confidence. Fuel Process. Technol. 39: 21-34.

Finkelman, R.B. 1995. Modes of occurrence of environmentally sensitive trace elements in coal. In Environmental Aspects of Trace Elements in Coal, edited by Swaine, D.W. \& Goodarzi, F. Dordrecht: Kluwer Academic Publishers. pp. 24-50.

Finkelman, R.B. \& Bunnell, J.E. 2003. Short Course A. Health Impacts of Coal: Should We Be Concerned? Arlington: The Society for Organic Petrology. pp. 1-57.

Finkelman, R.B. \& Gross, P.M.K. 1999. The types of data needed for assessing the environmental and human health impacts of coal. Int. J. Coal Geol. 40: 91-101.

Finkelman, R.B., Belkin, H.E. \& Zheng, B. 1999. Health impacts of domestic coal use in China. Proceedings of the National Academy of Sciences of the United States of America 96(7):
3427-3431.

Frankenberger Jr., W.T. \& Engberg, R.A. 1998. Environmental Chemistry of Selenium. New York: Marcel Dekker. Inc.

Fuge, R. 2005. Anthropogenic Sources. In Essentials of Medical Geology, Impacts of the Natural Environment on Public Health, edited by Selinus, O., Alloway, B., Centeno, J.A., Finkelman, R.B., Fuge, R., Lindh, U. \& Smedley, P. New York: Elsevier Academic Press. pp. 43-60.

Gürdal, G. 2011. Abundances and modes of occurrence of trace elements in the Çan coals (Miocene), Çanakkale-Turkey. Int . J. Coal Geol. 87: 157-173.

Gürdal, G. 2008. Geochemistry of trace elements in Çan coal (Miocene), Çanakkale, Turkey. Int. J. Coal Geol. 74: 28-40.

Huang, Y., Jin, B., Zhong, Z., Xiao, R., Tang, Z. \& Ren, H. 2004. Trace elements ( $\mathrm{Mn}, \mathrm{Cr}, \mathrm{Pb}, \mathrm{Se}, \mathrm{Zn}, \mathrm{Cd}$ and $\mathrm{Hg}$ ) in emissions from a pulverized coal boiler. Fuel Process. Technol. 86: 23-32.

Huggins, F.E. 2002. Overview of analytical methods for inorganic constituents in coal. Int. J. Coal Geol. 50: 169-214.

Keegan, T.J., Farago, M.E., Thornton, I., Hong, B., Colvile, R.N., Pesch, B., Jakubis, P. \& Nieuwenhuijsen, M.J. 2006. Dispersion of As and selected heavy metals around a coalburning power station in central Slovakia. Sci. Total Envir. 358: 61-71.

Ketris, M.P. \& Yudovich, Ya.E. 2009. Estimations of Clarkes for Carbonaceous biolithes: World averages for trace element contents in black shales and coals. Int. J. Coal Geol. 78: 135-148.

Liechti, P., Roe, F.W. \& Haile, N.S. 1960. The Geology of Sarawak, Brunei and the Western Part of North Borneo. British Territories in Borneo: Geological Survey Dept.p. 360.

Liu, G., Yang, P., Peng, Z. \& Chou, C.L. 2004. Petrographic and geochemical contrasts and environmentally significant trace elements in marine-influenced coal seams, Yanzhou mining area, China. J. Asian Earth Sci. 23: 491-506.

Liu, G.J.,Zheng, L.G., Gao, L.F., Zhang, H.Y. \& Peng,Z.C. 2005 The characterization of coal quality from the Jining coalfield. Energy 30: 1903-1914.

Miller, B.G. 2011. Clean Coal Engineering Technology. New York: Elsevier Inc. p. 696.

Querol, X., Fernandes-Turiel, J.L. \& Lopez-Soler, A. 1995. Trace elements in coal and their behaviour during combustion in a large power station. Fuel 74: 331-343.

Raask, E. 1985b. The mode of occurrence and concentration of trace elements in coal. Prog. Energy Combust. Sci. 11: 97-118.

Radenovic, A. 2006. Inorganic constituents in coal. Kem. Ind. 55: 65-77.

Ren, D., Zhao, F., Wang, Y. \& Yang, S. 1999. Distributions of minor and trace elements in Chinese coals. Int.J. Coal Geol. 40: 109-118.

Seredin, V.V. \& Finkelman, R.B. 2008. Metalliferous coals: A review of the main genetic and geochemical types. Int. J. Coal Geol. 76: 253-289.

Swaine, D.J. \& Goodarzi, F. 1995. Environmental Aspects of Trace Elements in Coal. Dordrecht: Kluwer Academic Publishers. p. 312.

Swaine, D.J. 1990. Trace Elements in Coal. Sydney: Butterworths. p. 278.

Sia, S.G. \& Abdullah, W.H. 2012a. Enrichment of arsenic, lead, and antimony in Balingian coal from Sarawak, Malaysia: Modes of occurrence, origin, and partitioning behaviour 
during coal combustion. Int. J. Coal Geol. 101: 1-15.

Sia, S.G. \& Abdullah, W.H. 2012b. Geochemical and petrographical characteristics of low-rank Balingian coal from Sarawak, Malaysia: Its implications on depositional conditions and thermal maturity. Int. J. Coal Geol. 96-97: 22-38.

Schweinfurth, S.P. 2003. Coal - A Complex Natural Resource, An overview of Factors Affecting Coal Quality and Use in the United States. U.S. Geological Survey Circular 1143. p. 39.

Spears, D.A. \& Zheng, Y. 1999. Geochemistry and origin of elements in some UK coals. Int. J. Coal Geol.38: 161-179.

Stach, E., Mackowsky, M-Th., Taylor, G.H., Chandra, D., Teichmüller, M. \& Teichmüller, R. 1982. Coal Petrology (3 ed). Borntraeger, Berlin and Stuttgard: Gebrüder. p. 535.

Suárez-Ruiz, I. \& Ward, C.R. 2008. Basic factors controlling coal quality and technological behavior of coal. In Applied Coal Petrology - The Role of Petrology in Coal Utilization, edited by Suárez-Ruiz, I. and Crelling, J.C. New York: Academic Press. pp. 19-59.

Sun, R., Liu, G., Zheng, L. \& Chou, C.L. 2010. Geochemistry of trace elements in coals from the Zhuji Mine, Huainan Coalfield, Anhui, China. Int. J. Coal Geol. 81: 81-96.

Tang, J., Xiao, T., Wang, S., Lei, J., Zhang, M., Gong, Y., Li, H., Ning, Z. \& He, L. 2009. High cadmium concentrations in areas with endemic fluorosis: A serious hidden toxin? Chemosphere 76: 300-305.

Tewalt, S.J., Bragg, L.J. \& Finkelman, R.B. 2001. Mercury in U.S. Coal - Abundance, distribution, and modes of occurrence. USGS Fact Sheet FS-095-01. p. 4.

Thornton, I., Farago, M.E., Keegan, T., Nieuwenhuijsen, M.J., Colvile, R.N., Pesch, B., Ranft, U., Miskovic, P., Jakubis, P. \& EXPASCAN study group. 2003. Environmental impacts, exposure assessment and health effects related to arsenic emissions from a coal-fired power plant in Central Slovakia; the EXPASCAN Study. Arsenic Exposure and Health Effects V.pp. 39-49.

US Public Law. 1990. Clean Air Act Amendments of 1990. Public Law 101-549. p. 441.

US EPA (US Environmental Protection Agency) 2000. The Clean Air Act.

Vassilev, S.V. \& Braekman-Danheux, C. 1999. Characterization of refuse-derived char from municipal solid waste 2 . Occurrence, abundance and source of trace elements. Fuel Process. Technol. 59: 135-161.
Vassilev, S.V. \& Vassileva, C.G. 1996. Occurrence, abundance and origin of minerals in coals and coal ashes. Fuel Process. Technol. 48: 85-106.

Vejahati, F., Xu, Z. \& Gupta, R. 2010. Trace elements in coal: Associations with coal and minerals and their behavior during coal utilization - A review. Fuel 89: 904-911.

Wang, W., Qin, Y., Wang, J., Li, J. \& Weiss, D.J. 2010. A preliminary method for determining acceptable trace element levels in coal. Energy 35: 70-76.

Ward, C.R. 2002. Analysis and significance of mineral matter in coal seams. Int. J. Coal Geol. 50: 135-168.

Wolfenden, E.B. 1960. The Geology and Mineral Resources of the Lower Rajang Valley and Adjoining Areas, Sarawak. Memoir 11, Geological Survey of British Borneo.p. 167.

Zhang, J., Ren, D., Zheng, C., Zeng, R., Chou, C. \& Liu, J. 2002. Trace element abundances in major minerals of Late Permian coals from southwestern Guizhou province, China. Int. J. Coal Geol. 53: 55-64.

Zhao, Y., Zhang, J., Huang, W., Wang, Z., Li, Y., Song, D., Zhao, F. \& Zheng, C. 2008. Arsenic emission during combustion of high arsenic coals from Southwestern Guizhou, China. Energ. Conv. Manage. 49: 615-624.

Zheng, B., Ding, Z., Huang, R., Zhu, J., Yu, X., Wang, A., Zhou, D., Mao, D. \& Su, H. 1999. Issues of health and disease relating to coal use in southwestern China. Int.J. Coal Geol. 40: $119-132$.

Say-Gee Sia* \& Wan Hasiah Abdullah Geology Department, University of Malaya 50603 Kuala Lumpur, Federal Territory Malaysia

Say-Gee Sia*

Minerals and Geoscience Department Malaysia 20th Floor, Tabung Haji Building, Jalan Tun Razak 50658 Kuala Lumpur, Federal Territory Malaysia

*Corresponding author; email: siasg@siswa.um.edu.my

Received: 4 April 2016

Accepted: 22 July 2016 